\title{
Nitridation of grate in a biomass-fired boiler
}

Montgomery, Melanie; Dahl, Kristian V.; Grumsen, Flemming B.; Kværndrup, Frederik B.; Hald, John

Published in:

Materials and Corrosion

Link to article, DOI:

$10.1002 /$ maco.201810630

Publication date:

2019

Document Version

Peer reviewed version

Link back to DTU Orbit

Citation (APA):

Montgomery, M., Dahl, K. V., Grumsen, F. B., Kværndrup, F. B., \& Hald, J. (2019). Nitridation of grate in a biomass-fired boiler. Materials and Corrosion, 70(1), 1461-1475. https://doi.org/10.1002/maco.201810630

\section{General rights}

Copyright and moral rights for the publications made accessible in the public portal are retained by the authors and/or other copyright owners and it is a condition of accessing publications that users recognise and abide by the legal requirements associated with these rights.

- Users may download and print one copy of any publication from the public portal for the purpose of private study or research.

- You may not further distribute the material or use it for any profit-making activity or commercial gain

- You may freely distribute the URL identifying the publication in the public portal

If you believe that this document breaches copyright please contact us providing details, and we will remove access to the work immediately and investigate your claim 


\title{
Nitridation of grate in a biomass fired boiler
}

\author{
Melanie Montgomery*, Kristian V. Dahl, Flemming B. Grumsen, Frederik B. \\ Kværndrup, John Hald \\ DTU Mechanical Engineering, Produktionstorvet - Building 425, DK 2800 Kgs. Lyngby, \\ Denmark \\ *Corresponding author: Melanie Montgomery_mmon@mek.dtu.dk;
}

\begin{abstract}
After a straw fired power plant in Denmark had been in operation for 16 years with 93815 hours operation, there was a need for overlay welding repair of the grate due to decrease in wall thickness from erosion/corrosion. The grate consisted of $15 \mathrm{Mo} 3$ (Werkstoff nr. 1.5415) tubes where water/steam flows through, which were welded together with fins, and where one side faced the combustion zone coming into contact with the fuel (the side that required weld overlay). The water/steam temperature was $320^{\circ} \mathrm{C}$ and the surface metal temperature was estimated to be $350^{\circ} \mathrm{C}$. However, there were difficulties when trying to overlay weld the grate as the weld pool was unstable.

Microhardness measurements on cross-sections of the tubes revealed a higher hardness of the tube facing the combustion zone compared to opposite the combustion zone. In addition, there was higher hardness adjacent the combustion side than the steam/water side. Analysis of etched cross-sections with light optical and scanning electron microscopy revealed the presence of acicular structures at the convex surface. Further analysis has been conducted with XRD and a LECO nitrogen analyser indicating the presence of iron nitrides. Reasons for their evolution and implications for the repair welding are discussed.
\end{abstract}

Keywords: biomass boiler, straw, iron nitrides, welding problems

\section{Introduction}

This paper describes the microstructure evolution of the $15 \mathrm{Mo} 3$ steel (Werkstoff $\mathrm{nr}$ 1.5415, EN $16 \mathrm{Mo} 3$ ) grate at a straw firing plant due to gas-metal interactions. The fuel at this plant is primarily wheat and barley straw (no woodchips). The location of the component is shown in Figure 1 . The steam temperature of the grate is $320^{\circ} \mathrm{C}$ and estimated metal temperature is $350^{\circ} \mathrm{C}$ based on the estimated heat flux in the area. Primary air (from the air preheater with temperature 
$220^{\circ} \mathrm{C}$ ) is introduced to the combustion zone via holes in the fins of the grate to result in optimal combustion conditions on the grate. During summer shutdown in 2016 after thickness measurements of the grate, it was concluded that the grate should be repaired with weld overlay as the tubes were approaching a critical thickness. The exposure time had been 93815 hours. However after trials with welding, the weld pool was unstable and therefore this repair was only undertaken in a few locations where it was possible. To understand reasons for these problems, microstructural investigations of the grate tubes were undertaken comparing the combustion side and the backside which is only in contact with air.

When biomass is combusted via grate-firing, flue gas and aerosol particles are released, and these have previously been shown to result in high temperature corrosion for components at temperatures over $500^{\circ} \mathrm{C}$. On the grate, during combustion there are a wide range of chemical reactions due to pyrolysis and gasification of the fuel resulting in many different gas species in the grate area (Figure 2)[1]. However the temperature of the grate is $350^{\circ} \mathrm{C}$ and therefore much lower than superheaters, and the corrosion attack is slower due to the lower temperature, however the exposure time has been over 90000 hours, and this could result in some changes in the tube microstructure/composition which have previously not been envisaged.

\section{Materials and Methods}

Tubes of steel type 15Mo3 type steel (Table 1) were removed from the grate for further analysis. The tubes have nominal specifications $38 \mathrm{~mm}$ outer diameter and $4 \mathrm{~mm}$ wall thickness.

Cross-sections were prepared using normal metallographic techniques, and were etched with $2 \%$ Nital (nitric acid in ethanol) and investigated with light optical microscopy. Microhardness profiles were conducted with a Vickers load of $25 \mathrm{~g}$ across the tube facing the combustion zone (combustion side) and on the backside using a $25 \mathrm{~g}$ load. Scanning electron microscopy (SEM) of the etched and unetched cross-sections of tubes was undertaken with a JEOL 5900 using detectors for both secondary electrons (SE) and back scattered electrons (BSE). Elemental analysis was undertaken with the Oxford Instruments energy dispersive x-ray spectroscopy (EDS) equipment on the JEOL microscope using acceleration voltages of either 13 or $20 \mathrm{keV}$. 
Thin film samples were prepared from the area closest to the convex surface using an electropolishing solution (6\% perchloric acid, 10\% ethylene glycolmonobutyl ether, 5\% deionised water, balance ethanol at $15.5 \mathrm{~V}$ ) and investigated with a FEI Titan Analytical 80300ST Transmission Electron Microscopy (TEM) with EDS analysis.

All cross-sections were coated with carbon before analysis. X-ray diffraction (XRD) was conducted with a Bruker D8 Discovery using a Cr source and the analysis was conducted with a parallel beam at different locations on the tube (Figure 3). XRD was conducted on a) the convex surface of the steel both on the combustion side and backside of the tube i) without removal of corrosion products and ii) with total oxide removal (undertaken after stepwise removal described in b). There was further analysis on the b) combustion side after light polishing to remove some oxide so both the metallic surface and oxide were apparent, and then after total oxide removal giving a polished surface. In addition, the oxide was removed from c) the concave side (steamside), and diffraction was undertaken for both the combustion side and the backside locations. Determination of nitrogen content at the combustion side and backside locations (Figure 3b) was undertaken using a TN500 LECO Nitrogen Determinator. The quantification of nitrogen is based on the change in thermal conductivity in a constant stream of helium where the influence of $\mathrm{O}, \mathrm{H}$ and $\mathrm{C}$ has been amended previously. Four samples from each location were made by first cutting $3 \mathrm{~mm}$ slices of the tube, and then cutting a $4 \mathrm{~mm}$ section from the tube wall (as shown in in Figure 3b). The convex and concave sides were ground away so the analysis did not include any corrosion products. Therefore the analyses are an average of the nitrogen concentration in the tube wall thickness on the combustion side and backside, not including the area closest to the convex and concave surfaces. The resulting samples could easily fit in the 9 $\mathrm{mm}$ diameter ceramic crucible used in the LECO analyser and weighed 0.5-0.7 mg. The LECO analyser was calibrated with two standards $(0.5 \mathrm{wt} . \% \mathrm{~N}$ and $0.05 \mathrm{wt} . \% \mathrm{~N}$ in steel).

Thermodynamic equilibrium predictions were performed in Thermo-Calc version 2018b [3] using the Thermo-Calc Software TCFE Steels/Fe-alloys database version 9. For the predictions, the equilibrium phases graphite and diamond were removed from calculations in order to 
stabilise cementite. Diffusion simulations were performed in the Thermo-Calc diffusion module (DICTRA) using mobility data from the Thermo-Calc Software MOBFE database version 4.

\section{Results}

\subsection{Microhardness measurements}

Microhardness measured across the wall thickness of the tube is shown in Figure 4. On the backside, the hardness was constant throughout the wall thickness of the tube from convex to concave side (water/steam side) at a level of 150-200 HV. For the combustion side, the hardness was higher on the convex surface up to 450-500 HV, and then gradually decreased to be constant $1.5 \mathrm{~mm}$ from the water/steam side. However, even in this low hardness region close to the concave side, the hardness was 250-330 HV, i.e. approximately $70 \mathrm{HV}$ higher on the combustion side compared with the backside.

\subsection{Microstructure and microstructural analysis}

Both light optical and scanning electron microscopy was undertaken for the cross-sectioned tube to investigate both the oxide and the $15 \mathrm{Mo} 3$ steel.

\subsubsection{Oxide}

Light optical microscopy revealed the heterogeneous nature of the corrosion products on the combustion side of the tube. In Figure 5a, the presence of different oxides were revealed by the different greyscales. The location of the various oxides was not specific to whether the oxide was closest to the metal or closest to the flue gas. This is in contrast to the normal case where due to the varying partial pressures of oxygen through the oxide to the metal interface, the same oxide is always present at the oxide-metal interface, etc. As shown in Figure 5b, white features within the oxide were observed in some areas around the tube, presumably an unoxidised metallic phase. In addition in Figure 5c, acicular features (needles) were just visible at the alloy adjacent the oxide-metal interface. 
The back scattered electron (BSE) images revealed similar to the light optical micrographs that the oxide consisted of different oxides that appeared darker and lighter according to average atomic number (Figure 6) and the location of the darker and lighter oxides was not consistent with respect to the surface of the alloy. The main components of the oxide were Fe and oxygen, and other elements such as $\mathrm{Mn}, \mathrm{Si}, \mathrm{S}, \mathrm{Mo}$ were only present in amounts $<1 \mathrm{wt} . \%$, therefore only oxygen wt.\% based on $\mathrm{Fe}$ and $\mathrm{O}$ content are given in Figure 6. The lighter oxide (with respect to the backscatter contrast) was measured to have an oxygen content between $28-33 \mathrm{wt} . \%$, while the darker oxide had a higher measured oxygen content of 37-39 wt.\%. It is therefore evident that the darker oxide had a higher oxygen content. The oxygen content of $\mathrm{Fe}_{3} \mathrm{O}_{4}$ and $\mathrm{Fe}_{2} \mathrm{O}_{3}$ are expected to be 28 and $30 \mathrm{wt} . \%$, respectively. A compound with higher oxygen content could be FeOOH, which would have $36 \mathrm{wt} . \%$. For comparison, $25 \mathrm{wt} . \%$ O content was measured for the steamside oxide (which is magnetite) under the same conditions. Care should be taken when comparing oxygen wt.\% values as oxygen is a lighter element and cannot be analysed with high accuracy level with EDS, however the dark grey areas consistently had a higher oxygen concentration than the lighter grey oxide. Within the oxide, needles of a "metallic phase" were also present (Figure 7a) however in other areas there was preferential internal attack revealed as fingers of unattacked metal protruding from the metal surface (Figure $7 \mathrm{~b}$ ).

\subsection{2. $15 \mathrm{Mo3}$ steel}

Light optical microscopy after etching revealed the ferrite-pearlite structure in the alloy which was present throughout the tube thickness (Figure 8a). This structure was observed on the backside of the tube and on the tube close to the steamside. The acicular structure together with ferrite and pearlite (Figure 8b) was present near the surface on the combustion side only. The

presence of pearlite throughout the tube indicates that the operation temperature had been within a temperature range where pearlite is not degraded (spheroidised).

Higher magnification scanning electron micrographs at various positions through the tube wall from the steamside to the combustion side of the tube revealed that traces of acicular structure were present first at about 1.5-2 $\mathrm{mm}$ from the steamside, and the amount of acicular structure increased with distance away from the concave steamside surface (Figure 9). These acicular 
phases went through grains, did not have the tendency to be present on grain boundaries, and coexisted with the pearlite. Analysis of the composition of these needles with EDS gave an indication of nitrogen, only when the needles were adjacent the combustion side; $3-4$ wt.\% $\mathrm{N}$ was detected when using an acceleration voltage of $13 \mathrm{keV}$. There are however various factors in the present case that make analysis of nitrogen difficult: Nitrogen is a light element and therefore it is generally difficult to analyse for using EDS and even more so when it is only present in a relatively low amount in e.g. the $\mathrm{Fe}_{4} \mathrm{~N}$ phase (6 wt.\%), and the acicular structures are thin and lying in a ferrite matrix so that the analysis will include response from the matrix. Analysis of the acicular features did not show an increase of any of the substitutional alloying elements i.e. Cr or Mo. A slightly darker grey tone was observed on the backscattered images of the acicular structures adjacent the oxide indicating a phase with lower atomic weight (see Figure 6a and Figure 7b). To obtain an improved analysis, a TEM sample was investigated, and although there are similar challenges for EDS analysis, the influence of interaction volume is significantly reduced. Figure 10 shows the range of 3 EDS analyses of the needle and the surrounding matrix indicating nitrogen levels of up to $1.7 \mathrm{wt} . \%$ in the needle and no nitrogen was detected in the matrix.

\subsection{X-ray diffraction}

Three different locations were measured with XRD as shown in Figure 3 and phase analysis is summarised in Table 2. X-ray diffraction (1a) was used to compare the oxides from the combustion side and the backside of the tube by analysing the unpolished specimen from the convex backside and convex combustion side (Figure 11). The corrosion products from the combustion side detected with XRD were magnetite, goethite $(\alpha-\mathrm{FeOOH})$ and lepidocrocite $(\gamma-$ $\mathrm{FeOOH}$ ) which substantiated the oxygen measurements from EDS in Figure 6, and on the backside, magnetite and hematite were detected. In addition, there was an indication of iron nitride $\left(\mathrm{Fe}_{4} \mathrm{~N}\right)$ on the combustion side. To obtain more information below the oxide-metal interface on the combustion side, measurements (2) were also done where the sample surfaces were slightly polished (semi-polished in Table 2) and finally where the oxide was fully removed

(polished away). The corrosion products removed after slight polishing were also analysed and magnetite, lepidocrocite and goethite were identified and there was no indication of $\mathrm{Fe}_{4} \mathrm{~N}$. The 
diffractogram on the semi-polished surface revealed only corrosion products of lepidocrocite and goethite. On the polished surface, ferrite was detected and a small amount of $\gamma-\mathrm{Fe}_{4} \mathrm{~N}$ with a possible indication of $\varepsilon-\mathrm{Fe}_{2-3} \mathrm{~N}$. Comparison of the polished convex combustion side and backside (1b) in Figure 12 showed a tendency of a shift in the peaks to lower $2 \theta$ and slight peak broadening. For the polished concave side (3), this tendency was not observed i.e. there was no difference in either peak position or peak shape comparing the combustion side and backside (Figure 13).

\subsection{Nitrogen analysis}

The composition of the nitrogen as measured by the LECO nitrogen analyser was $0.072 \pm 0.003$ for the samples taken from the combustion side and $0.006 \pm 0.003$ for the backside. The results of the four samples are shown in Figure 14. Thus there was a 10 times higher concentration of nitrogen within the metal cubes from the combustion side and the measured amounts were reproducible. The measured contents are average compositions throughout the tube wall thickness and the concentration could therefore be expected to be higher at specific positions, e.g. at different distances from the combustion side surface to correlate with the observed differences in hardness and microstructure.

\section{Discussion}

The examination of the $15 \mathrm{Mo} 3$ tube from the grate indicates some reactions that have not previously been documented for grate tubes in a biomass plant. The results are summarised in Table 3 and indicate that there is a change in microstructure and hardness on the tube adjacent the combustion zone as well as an increased nitrogen content. Both light optical and scanning electron microscopy of Nital etched specimens revealed acicular (needle-like) structures within the ferrite-pearlite microstructure on the combustion side (convex side). Since pearlite is present throughout the steel with no signs of spheroidisation, this indicates that the component had not been exposed to unexpected high temperatures. The acicular phases were observed within grains and across grain boundaries (Figure 9), but were not present at the concave steamside or through the wall on the backside of the grate thus relating their formation to the combustion environment. 
From the LECO chemical analysis of the steel, it is clear that the nitrogen level was 10 times higher on the combustion side than the backside. This would lead to the conclusion that the surface of the steel at the fireside has suffered some degree of nitridation. The phase diagram for nitrogen and iron is shown in Figure 15 [4], which shows that the first stable phase to form is $\gamma$ $\mathrm{Fe}_{4} \mathrm{~N}$ and then $\varepsilon$-nitride with increasing nitrogen content. Investigations on the presence of nitrides at lower temperatures (using a nickel layer as a catalyst for the dissociation of ammonia) has revealed both $\gamma-\mathrm{Fe}_{4} \mathrm{~N}$ and $\varepsilon$-nitride at temperatures of $275^{\circ} \mathrm{C}$ [5] indicating that nitrides can form at even lower temperatures than shown on Figure 15. Grabke [6] showed that the maximum solubility of $\mathrm{N}$ in $\alpha$-iron was $0.1 \mathrm{wt} . \%$ at $590^{\circ} \mathrm{C}$ and this decreased at lower temperatures so iron nitrides could be expected with low nitrogen concentrations.

The conditions for pyrolysis and gasification leading to nitrogen release have been investigated using flow reactors, as measurements in an actual plant are difficult. Lang et al [7] reported that biomass releases $50 \%$ of Fuel-N (nitrogen originating from the fuel) up to temperatures of $400^{\circ} \mathrm{C}$ which would be at the front part of the grate and the remaining Fuel-N is released up to $700^{\circ} \mathrm{C}$. In some cases the nitrogen was retained in the char and in other cases it was released in gaseous form. Measurements of woody biomass tested in a batch reactor [8] showed that $\mathrm{NH}_{3}$ is the gaseous nitrogen compound with the highest concentration released on the grate which then was quickly converted to NOx compounds. Comparison of data [9] from various tests and assessments showed that the major nitrogen containing gas from pyrolysis was either $\mathrm{NH}_{3}$ or $\mathrm{HCN}$, and which of these components depends on many factors such as biomass type, gas atmosphere, presence of other minerals, whether nitrogen was present as lignin etc. The equilibrium between these two constituents is given by Equation 1:

$$
\mathrm{NH}_{3}+\mathrm{CO} \leftrightarrow \mathrm{HCN}+\mathrm{H}_{2} \mathrm{O} \quad \text { Eqt } 1
$$

It was found that wheat straw resulted in both $\mathrm{HCN}$ and $\mathrm{NH}_{3}$ as the major nitrogen species from pyrolysis, and reactor experiments showed that the presence of oxygen favours $\mathrm{HCN}$ formation [9]. Becidan et al [10] revealed that pyrolysis and gasification of biomass residue leads to more $\mathrm{NH}_{3}$ than $\mathrm{HCN}$ and the concentration of these gas species increased with increasing temperature. 
These reactor studies show that biomass combustion on the grate results in the presence of $\mathrm{NH}_{3}$ or HCN which could cause nitridation, before being converted to NOx.

Although there is no doubt that $\mathrm{NH}_{3}$ can cause nitridation compared to the slow reaction of $\mathrm{N}_{2}$, the role of $\mathrm{HCN}$ is probably marginal [4]. If $\mathrm{NH}_{3}$ is at $1 \mathrm{~atm}$. and at a temperature above $350^{\circ} \mathrm{C}$, then this would lead to complete dissociation of the $\mathrm{NH}_{3}$ [4], which is the starting point of nitridation of steel. However if this $\mathrm{NH}_{3}$ is quickly oxidised, then no nitridation will occur. Air is injected through holes in the grate to result in an oxidising atmosphere. Oxide is present on the surface of the grate so it can be assumed that there is partially oxidising conditions. It would be assumed that surface oxide is a barrier for ingress of $\mathrm{NH}_{3}$ to the surface of the metal. However experiments with preoxidation of iron revealed that nitridation accelerated due to the fact that the oxide catalysed the dissociation of $\mathrm{NH}_{3}$ [11]. When this happens, the $\mathrm{N}_{2}$ is adsorbed on the metallic surface and the hydrogen is released. Thus, although there is oxidizing conditions above the grate, nitridation of the tube can still occur. Grabke et al [12] proposed a layered structure due to oxynitridation where iron nitrides are present immediately below the oxide, and $\alpha$-iron + other nitride formers are present further away from the steel surface.

\subsection{Microstructural changes in the exposed $15 \mathrm{Mo3}$ steel tubes}

Nitrocarburisation of carbon steel AISI 1015 revealed a similar acicular structure as observed in this study below a white surface layer [13] which would support the conclusion that the grate tube has been nitrided. XRD indicates the presence of ferrite and a phase corresponding to $\gamma$ $\mathrm{Fe}_{4} \mathrm{~N}$ in some areas of the corrosion product on the tube surface, and there were also indications for the presence of $\varepsilon$-nitride $\mathrm{Fe}_{2} \mathrm{~N}$. The tubes analysed revealed a localised higher hardness at the surface immediately adjacent the combustion zone probably due to the presence of $\mathrm{Fe}_{4} \mathrm{~N}$. Since nitrogen is a light element and would be at $6 \mathrm{wt} . \%$ in $\mathrm{Fe}_{4} \mathrm{~N}$ if it is present, accurate analysis is beyond the capabilities of the scanning electron microscope used, especially when it is lying in thin structures within the ferrite matrix. No increase of other alloying elements such as $\mathrm{Cr}$ or Mo was measured within these acicular phases indicating that these must be iron based. Nonoxidised acicular phases were within the corrosion product adjacent the alloy surface which 
could explain why $\mathrm{Fe}_{4} \mathrm{~N}$ was identified within the oxide on the tube surface. Thermodynamic calculations (using ThermoCalc [3]) of phases present for this steel using the nominal analysis in Table 1 at $350^{\circ} \mathrm{C}$ is shown in Figure 16. Figure 16a shows that $\mathrm{N}_{2}$ gas is predicted to form rather quickly with addition of nitrogen to the material, however only few pores were observed and therefore the gas phase was suppressed in the calculations, which allowed different nitrides to form instead (Figure 16b). A number of different alloying element nitrides (Cr, Mo, Mn and Si) are predicted to form in low amounts until the nitrogen content is high enough to form first $\varepsilon$ nitride $\left(\mathrm{Fe}_{2}(\mathrm{~N}, \mathrm{C})\right)$ and then $\gamma$-nitride $\left(\mathrm{Fe}_{4} \mathrm{~N}\right)$ when the overall nitrogen content reaches approximately $1 \mathrm{wt} . \%$. Since the $\varepsilon$-nitride can take in $\mathrm{C}$, cementite is predicted to dissolve as the fraction of $\varepsilon$-nitride increases. Some changes in pearlite morphology could be observed when comparing the combustion side of the tube with the steamside (Figure 8), however it could not be proven that a dissolution of pearlite occurred. For iron-carbon alloys, the conversion of cementite to $\varepsilon$-nitride has been observed at temperatures above $500^{\circ} \mathrm{C}$ in dedicated nitriding exposures $[14,15]$. Cementite was not detected with XRD, however cementite is probably below detection limits of XRD (2-3 wt.\%). However $\gamma$-nitride and an indication of $\varepsilon$-nitride were revealed with XRD.

In addition to the amount of nitrogen present in stoichiometric nitrides such as $\mathrm{Fe}_{4} \mathrm{~N}$, nitrogen can be adsorbed at the nitride-matrix interface and be dissolved in octahedral interstices in the ferrite matrix [4]. XRD analysis of the convex side adjacent the combustion zone revealed a slight broadening of the ferrite peaks and also a shift of the ferrite peak to lower $2 \theta$. This could indicate the presence of nitrogen within the ferrite lattice and incorporation of metal nitrides within the ferrite lattice. The nitrogen solubility in the ferrite matrix also increases for Fe-M (M $=\mathrm{Cr}$, Mo etc.) alloys such as $15 \mathrm{Mo} 3$ compared to pure ferrite [16]. Nitriding of a 410 steel $(12 \% \mathrm{Cr})$ at $350^{\circ} \mathrm{C}$ resulted in $\mathrm{Fe}_{4} \mathrm{~N}$ formation (analysed with $\left.\mathrm{XRD}\right)$ and that the ferrite peak was broadened and shifted to lower $2 \theta$ [17]. Only when the nitriding temperature was increased to $400^{\circ} \mathrm{C}$, were $\mathrm{Cr}$ nitrides formed [17], so although they are thermodynamically stable, there can be a kinetic driving force to their formation. Similarly, precipitation of $\mathrm{Cr}$ nitrides was not observed $<425^{\circ} \mathrm{C}$ for a $18 \% \mathrm{Cr}$ stainless steel exposed to $\mathrm{NH}_{3}+\mathrm{CO}_{2}$ gas mixtures[18]. That no alloying element nitrides could be observed on the grate tube investigated could therefore be due 
to the low temperature where only interstitials can be expected to have significant mobility and not the larger metal atoms. Another possibility would be that the alloying element nitrides are very small. Since $15 \mathrm{Mo} 3$ is microalloyed with a nominal content of $0.3 \mathrm{wt} . \%$ of Mo, it cannot be excluded that formation of small Mo nitrides would contribute to increased hardness and shifts observed in the ferrite peaks.

Increased hardness of approximately $70 \mathrm{HV}$ was measured throughout the tube wall on the combustion side. In nitrocarburising studies, a surface layer of nitride would present a barrier against nitrogen diffusion, since nitrogen diffuses faster in the ferrite than in nitrides [19]. On these tubes there is no nitride layer, but acicular nitride within the ferrite so nitrogen would have access to the remaining bulk via the ferrite during exposure time. DICTRA simulations were used to investigate whether the diffusion kinetics at $320-350^{\circ} \mathrm{C}$ are fast enough to allow nitrogen diffusion through the wall thickness of the tube. The use of DICTRA for nitrogen diffusion into high vanadium steels has been found to give a good simulation compared to measured data [20]. Figure 17 shows the calculated nitrogen penetration through a $4 \mathrm{~mm}$ geometry, assuming a constant concentration of nitrogen of $1 \mathrm{wt} . \%$ as boundary concentration. Assuming a nitrogen concentration of $1 \mathrm{wt} . \%$ on the tube surface is when $\mathrm{Fe}_{4} \mathrm{~N}$ begins to be stable, due to the long exposure time the nitrogen will diffuse through the total thickness of the tube. In reality, the effective diffusion rate will not be constant, and will decrease if a high volume of alloying element nitrides or iron nitride are present [19] and also due to the lower temperature on the steamside, which can explain the lower penetration depth observed (based on hardness and microscopical analysis) in the actual tube. The in-diffusion of nitrogen can result in preferential reaction with alloying elements such as $\mathrm{Cr}$, Mo and Mn [12], where the nitrogen content is below $1 \mathrm{wt} . \%$ which could be a reason for the increased hardness through the tube. The presence of for example Mo nitrides was not revealed with scanning electron microscopy, however such precipitates have been observed to be sub-micron level at $580^{\circ} \mathrm{C}[21,22]$. At the low temperatures in this study, Mo is virtually immobile, so even if Mo nitrides were formed, they would remain as fine nitrides. After nitriding of carbon steels, hardness values of 30-35 HRC (equivalent to 300-340 HV) were measured which is just below the region observed for the grate [13]. The incorporation of fine $\mathrm{MoN} / \mathrm{MoN}_{2}$ led to an increase in hardness of up to $100 \mathrm{HV}$ for a steel with 
1 at.\% Mo (1.68 wt.\%) [22]. In addition, the ferrite peaks from XRD became broader and shifted to lower $2 \theta$ levels due to the presence of fine Mo nitrides precipitates [21]. However no difference in $\mathrm{x}$-ray diffractograms was perceived on the concave side (steamside) in the present investigation. The lack of shift and expansion for the ferrite peak on the concave side despite the increased hardness may be due to ageing of the nitrides. It was observed that ageing of nitrides at $500^{\circ} \mathrm{C}$ for a $\mathrm{Fe}-2 \% \mathrm{Cr}$ steel (at.\%) after 5 hours shifted the peak back to the position of the original ferrite peak, although it was still broader [23]. This is at a much higher temperature than the present exposure, but for a much shorter time period. Whether or not fine nanonitrides (Mo and/or $\mathrm{Cr}$ ) are present throughout the tube to the inner concave steamside could not be proven and advanced electron microscopy would be required to reveal their presence. The shift and broadening observed in the ferrite lattice observed on the convex side but not on the concave side could be due to the relative amount of nitrogen and metal nitrides present within the lattice which would be at a higher concentration on the convex side. The increased hardness could also occur when cementite is converted to epsilon nitride $[14,15]$ as previously discussed at the outer part of the tube closest to the combustion side, and the released carbon diffuses into the tube resulting in a slightly higher carbide formation. This mechanism has been observed in nitrocarburisation of iron and iron-carbon alloys [4].

\subsection{Corrosion products}

Usually for low alloy ferritic boiler steels at this temperature, magnetite or a Fe-Cr spinel would be expected to form close to the metal-oxide interface and hematite on the surface closest to the flue gas side, and this is consistent with the oxygen partial pressure gradient. However x-ray diffraction, light microscopy and scanning electron microscopy reveal a different result on the convex combustion side in this study. There were different layers which were not consistently located for example adjacent the metal surface. In addition to magnetite being present in the oxide, lepidocrocite $\gamma-\mathrm{FeOOH}$, also known as hydrohematite, and goethite $\alpha$-FeOOH were also detected with XRD on the combustion side. On the opposite tube side magnetite and hematite were detected as expected. The oxygen content measured by EDS of the darker grey oxide, which was sometimes adjacent the surface was higher which could correlate with a $\mathrm{FeOOH}$ compound. However, $\mathrm{FeOOH}$ is not usually found in combustion environments and should 
decompose to magnetite or maghematite when heated to $200-300^{\circ} \mathrm{C}$ [24] which is the estimated temperature of this component. It is suggested that the release of $\mathrm{H}_{2}$ during dissociation of $\mathrm{NH}_{3}$ may result in the formation of $\mathrm{FeOOH}$ species. Research on iron nitride formation described how limonite, which is a mixture of $\mathrm{FeOOH}$ compounds was used as a catalyst to dissociate ammonia and to form iron nitride [25] and this reaction proceeds from $350^{\circ} \mathrm{C}$. However there is a lower temperature limit to the formation of iron nitrides, as [26] reported that at $300^{\circ} \mathrm{C}$, iron nitride only formed when a fine nanostructure of iron was present, otherwise nitridation did not proceed.

\subsection{Consequences for boiler}

Nitrogen present within the steel either as interstitials atoms or in iron nitrides can disturb the welding process as $\mathrm{Fe}_{4} \mathrm{~N}$ is not stable at temperatures above $700^{\circ} \mathrm{C}$ [4,19]. This will lead to dissociation of iron nitride and release of nitrogen gas thus resulting in the instability of the weld pool and the difficulties in repair welding described by the owner of the plant. The tendency to denitrogenation of adsorbed nitrogen is significant with increasing temperatures and has been studied in great detail for $\alpha$-iron in various gas compositions [27,28]. If the nitrogen is to be removed from the tube, heating up to $500-700^{\circ} \mathrm{C}$ in reducing atmosphere is required $[4,19,25,27]$. However, this may not be a viable way as it can lead to formation of gas pores as revealed for a nitrided iron specimen exposed at $565^{\circ} \mathrm{C}$ in reducing atmosphere [4]. The presence of pores would not be desired for a pressure bearing component, and it is not known how deep these pores would be present. The presence of nitrides within the $15 \mathrm{Mo} 3$ component has not resulted in problems during operation, and only became apparent, when the component had to be repaired after 93815 hours service due corrosion and erosion. Experiences from the ammonia industry indicated that nitriding occurs above $380^{\circ} \mathrm{C}$ for ferritic steels and increased with temperature [29], but also that nitriding increased by a factor of 3-5 when high stresses were applied. Investigation of a 304L stainless steel heat exchanger in a catalytic reactor $\left(\mathrm{NH}_{3}+\mathrm{CO}_{2}\right)$ at $390^{\circ} \mathrm{C}-450^{\circ} \mathrm{C}$ also revealed nitridation, carburisation and oxidation [18]. A high nitrogen and carbon content was linked to Vickers hardness values of $>1000 \mathrm{HV}$ and spallation of brittle corrosion products which has not been a problem for the $15 \mathrm{Mo} 3$ grate but could be a problem with increase in alloying elements. The vibrating grate is a component which experiences 
continual mechanical stresses during plant operation and together with the presence of $\mathrm{NH}_{3}$ from pyrolysis and gasification of the straw, this makes it susceptible to nitridation.

\section{Conclusions}

The microstructure of the tubes on the grate was investigated in order to understand why there had been problems with welding.

I. The grate from a straw-firing plant suffered nitridation probably due to the presence of $\mathrm{NH}_{3}$ species released during combustion. This is revealed by light optical and scanning electron microscopy as well as XRD, and chemical analysis.

II. Nitridation had occurred to different extents through the tube where acicular $\mathrm{Fe}_{4} \mathrm{~N}$ was apparent on the surface closest to the combustion zone, and other fine nitride particles such as Cr, Mn or Mo may be present (but have not been identified) at lower concentrations throughout the steel.

III. The presence of the nitrided zone resulted in problems during welding, as nitrogen is outgassed on heating.

\section{Acknowledgements}

This paper was written under the FORSKEL project "Biomass Corrosion Management" with financial support from Energinet.dk and Ørsted. Added Values are acknowledged for the initial investigations and discussions. Thomas Christiansen (DTU-Mechanical Engineering) is acknowledged for fruitful discussions. Thanks to Verdo, owners of the Maribo Sakskøbing plant, for allowing publication of these results. 
References

1. M.C. Diaz-Ramirez, Ph.D Thesis, University of Zaragoza, Spain. Published by Springer International, 2015.

2. Stahlschlüssel, Verlag Stahlschlüssel Wegst GmbH, 1995.

3. J.O Andersson, T. Helander, L. Höglund, P.F. Shi, B. Sundman, Calphad 2002 26, 273.

4. E.J. Mittemejer, M.A.J. Somers, Thermochemical Surface Engineering of Steels, Woodhead Publishing Series in Metals and Surface Engineering: Elsevier Ltd. 2015.

5. E.H. du Marche van Voorthuysen, D.O. Boerma, N.G. Chechenin, Metallurgical and Materials Transactions A 200233 A 2593.

6. H.J. Grabke, Zeitschrift für Physikalische Chemie Neue Folge, 1976 100, 185.

7. T. Lang, A.D. Jensen, P.A. Jensen, Energy Fuels 2005, 19, 1631.

8. G. Stubenberger, R. Scharler, S. Zahirovic, I. Obernberger, Fuel 2008, 87, 793.

9. Q. Ren, C. Zhao, Renewable Sustainable Energy Rev. 2015 50, 408.

10. M. Becidan, Ø. Skreiberg, J.E. Hustad, Energy Fuels 2007, 21, 1173.

11. P.B. Friehling, F.W. Poulsen, M.A.J. Somers, Z. Metallkd. 2001, 92, 589.

12. H.J. Grabke, S. Strauss, D. Vogel, Materials and Corrosion 2003, 54, 895.

13. D. Pye, Practical nitriding and ferritic nitrocarburizing, ASM International 2003.

14. E.J. Mittemeijer, W.T.M. Straver, P.F. Colijn, P.J. van der Schaaf, J.A. van der Hoeven, Scr. Metall. 1980, 14, 1189.

15. H. Göhring, A. Leineweber, E.J. Mittemeijer, Metall. Mater. Trans. A, 2016, 47A, 4411.

16. M.A.J. Somers, R.M. Lankreijer, E.J Mittemeijer, Philos. Mag. A, 1989, 59, 353.

17. P. Corengia, G. Ybarra, C. Moina, A. Cabo, E. Broitman, Surf. Coat. Technol. 2004, 18763.

18. H.J. Grabke, Materials and Corrosion 2005, 56, 384.

19. E.J. Mittemejer, Fundamentals of nitriding and nitrocarburising: ASM Handbook Steel Heat Treating Fundamentals and Processes, 4A, ASM International 2013.

20. H. Larsson, J. Ågren, Metallurgical and Materials Transactions A 2004 35A, 2799.

21. H. Selg, E. Bischoff, S.R. Meka, R.E. Schacherl, T. Waldenmaier, E.J. Mittemeijer, Metall. Mater. Trans. A, 2013, 44, 4059.

22. T. Steiner, S.R. Meka, B. Rheingans, E. Bischoff, T. Waldenmaier, G. Yeli, T.L. Martin, P.A.J. Bagot, M.P. Moody, E.J. Mittemeijer, Philos. Mag. 2016, 96:15, 1509.

23. T. Steiner, M. Akhlaghi, S.R. Meka, E.J. Mittemeijer, J. Mater. Sci. 2015, 50, 7075.

24. T.S. Gendler, V.P. Shcherbakov, M.J. Dekkers, A.K. Gapeev, S.K. Gribov, E. McClelland, Geophys. J. Int. 2005, 160, 815.

25. N. Tsubouchi, H. Hashimoto, Y. Ohtsuka, Catal. Lett. 2005, 105, 203.

26. W.P. Tong, N.R. Tao, Z.B. Wang, J. Lu, K. Lu: Science 2003, 299, 686.

27. H.J. Grabke, Berichte der Bunsengesellschaft 1968, 72, 533.

28. H.J. Grabke, Berichte der Bunsengesellschaft 1968, 72, 541.

29. H.D. Marsch: Plant/Oper. Prog. 1982, 1, 152. 
Figure and Table captions

Figure 1: Schematic of Maribo Sakskøbing plant showing vibrating grate investigated.

Figure 2: Schematic of gas release over a sloping grate. Reprinted from [1]with permission from Springer International 2015.

Figure 3: Schematic showing areas where a) XRD and b) LECO analysis were undertaken.

Figure 4: Hardness measurements comparing the combustion side and the backside of the tube.

Figure 5: Light optical micrograph (without etching) close to combustion zone showing a) varying oxide composition on surface, b) needle like structures within the oxide and c) at the metallic surface

Figure 6: Wt.\% of oxygen measured with $13 \mathrm{keV}$ on different areas of oxide showing different BSE contrast a ) and b) are at combustion side and c) is at steamside. Only Fe and $\mathrm{O}$ considered (other elements were $<1 \mathrm{wt} . \%$ ).

Figure 7: BSE micrographs revealing morphology of different areas at the corrosion front on the combustion side a) acicular structure within a dark oxide b) internal oxidation at the corrosion front.

Figure 8: Light optical microscopy after etching revealing a) pearlite-ferrite structure close to steamside b) acicular phase adjacent combustion side.

Figure 9: SE micrographs of microstructure on the combustion side showing variation with distance from steamside.

Figure 10: TEM micrographs of needle and EDS analysis of needle and matrix.

Figure 11: Comparison of x-ray diffractograms from unpolished combustion side and unpolished backside. Dotted line indicates ferrite peaks.

Figure 12: Ferrite peaks on convex side: comparison of combustion side and backside after removal of oxide.

Figure 13: Ferrite peaks on concave side: comparison of combustion side and backside after removal of oxide.

Figure 14: Comparison of nitrogen content from the combustion side to backside of tube on grate.

Figure 15: Phase diagram of iron and nitrogen with respect to temperature (reprinted from [4] with permission from Elsevier 2015 ).

Figure 16: Thermodynamic prediction using ThermoCalc [3] of a) phases present within $15 \mathrm{Mo} 3$ at $350^{\circ} \mathrm{C}$ with increasing nitrogen content, b) calculation where gas phase is suppressed.

Figure 17: DICTRA simulations [3] to model the nitrogen concentration through a $4 \mathrm{~mm}$ tube with respect to varying times and temperatures.

Table 1: DIN standard Wkstf 1.5415 for grade $15 \mathrm{Mo} 3$ steel (taken from Stahlschlüssel[2]), and nominal analysis and SEM analysis.

Table 2: Phases identified with x-ray diffraction

Table 3: Summary of results from combustion side and backside of the tube 
FIGURES

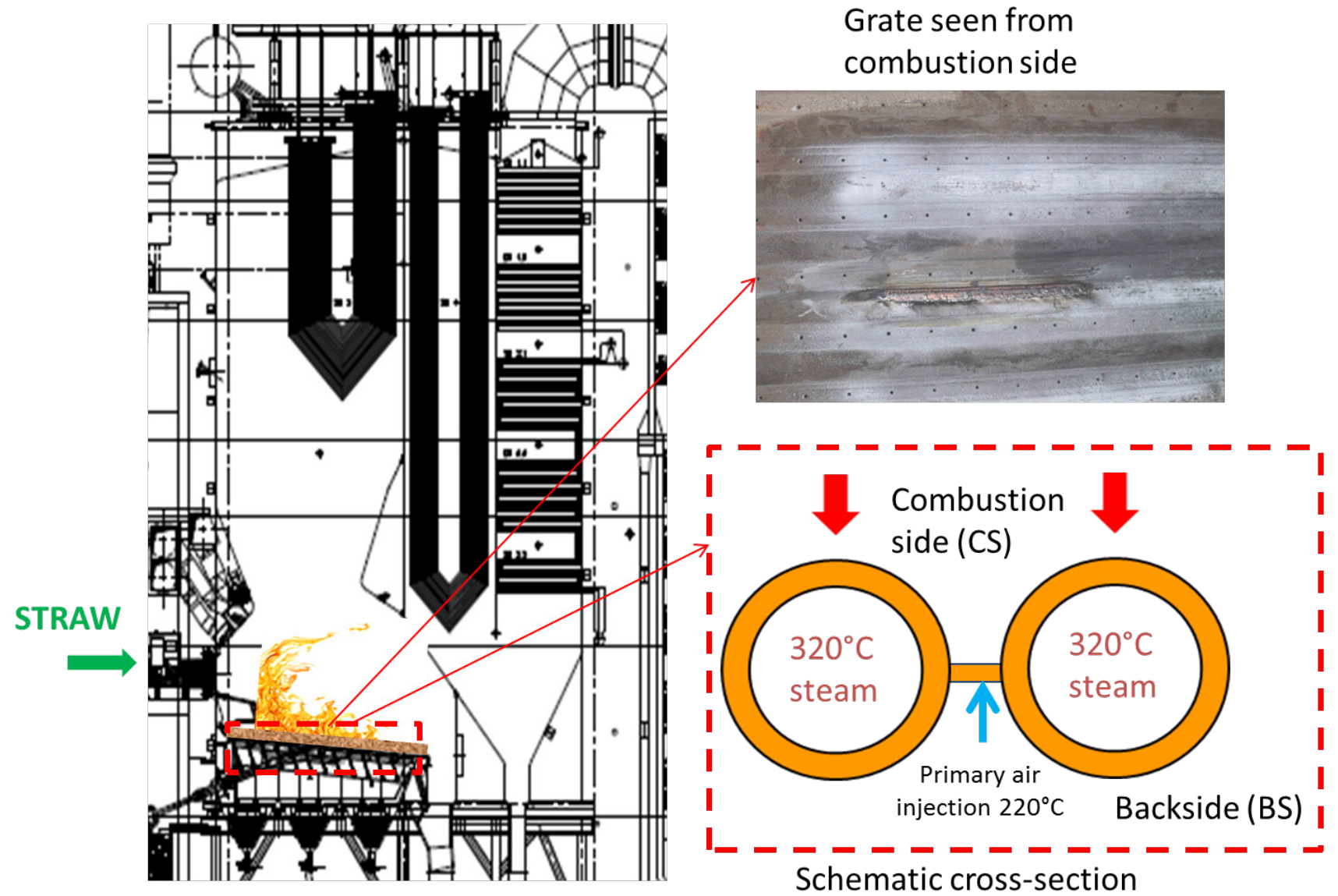

Figure 1: Schematic of Maribo Sakskøbing plant showing vibrating grate investigated. 


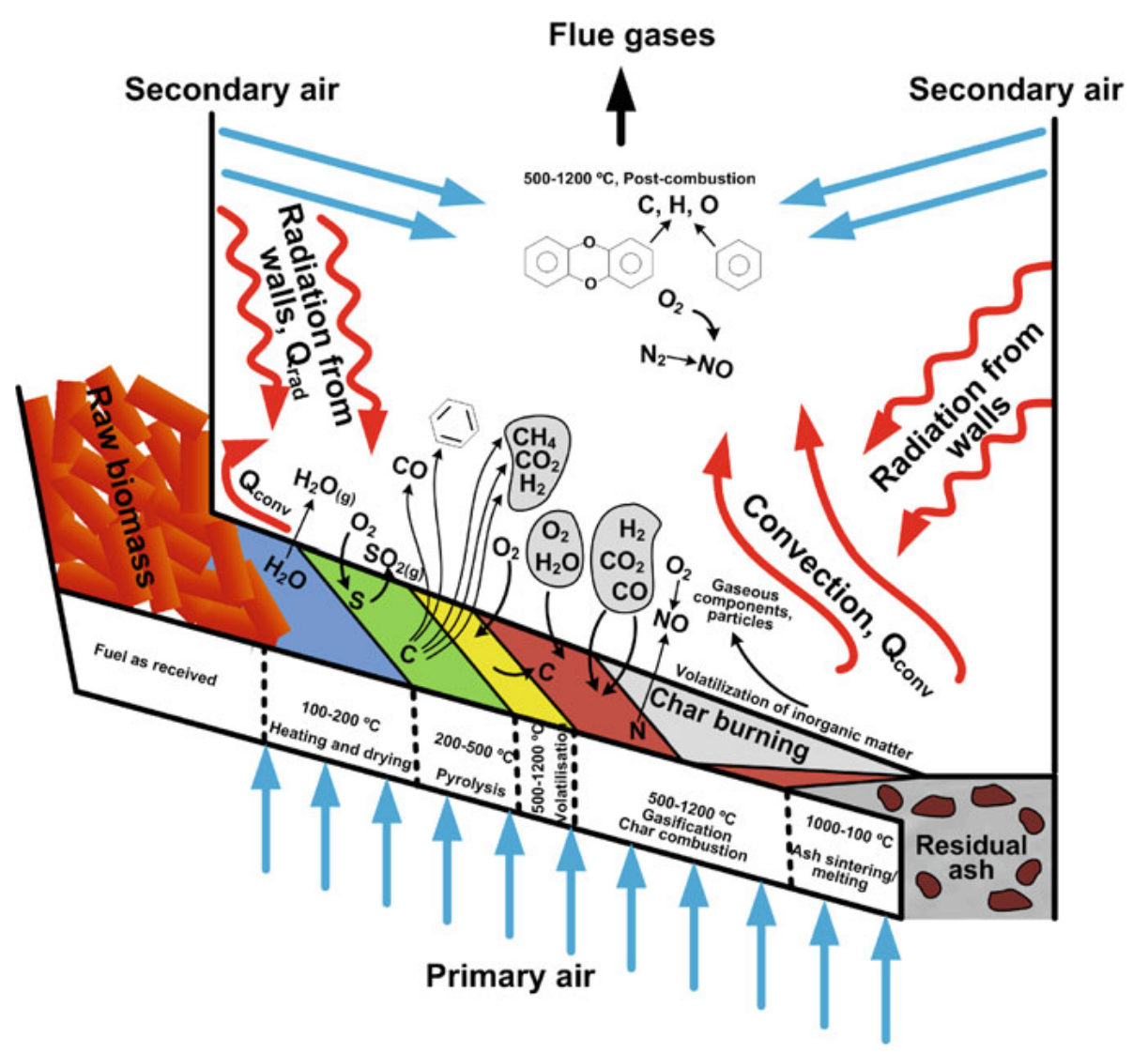

Figure 2: Schematic of gas release over a sloping grate. Reprinted from [1] with permission from Springer International 2015.

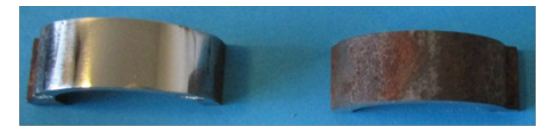

2) analysis on convex side after partial and complete oxide removal.

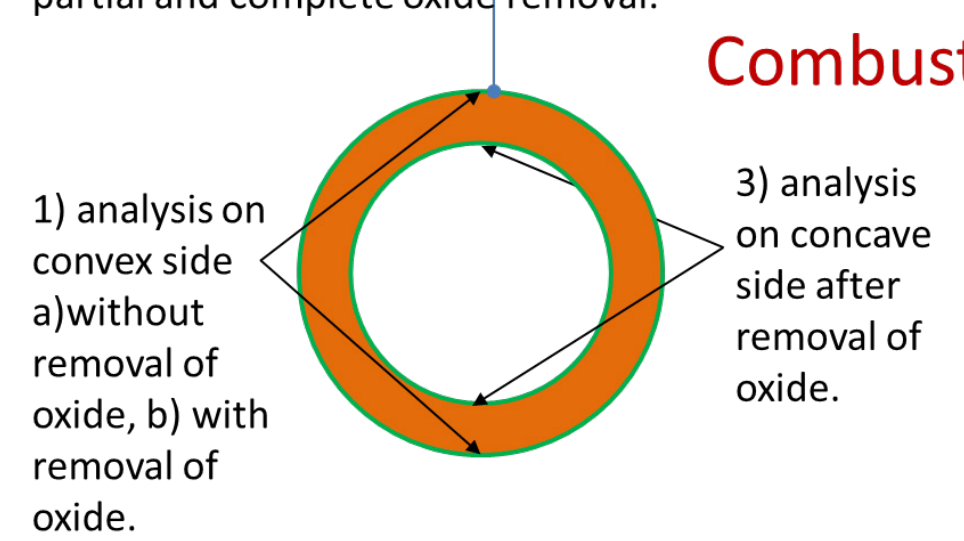

a) XRD analysis

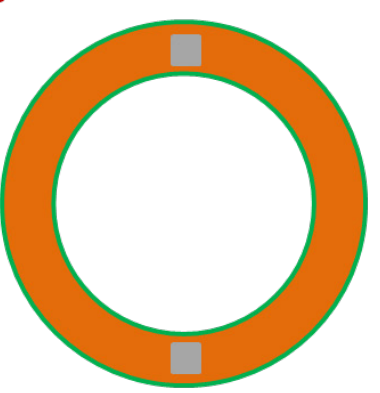

b) LECO analysis

Figure 3: Schematic showing areas where a) XRD and b) LECO analysis were undertaken. 


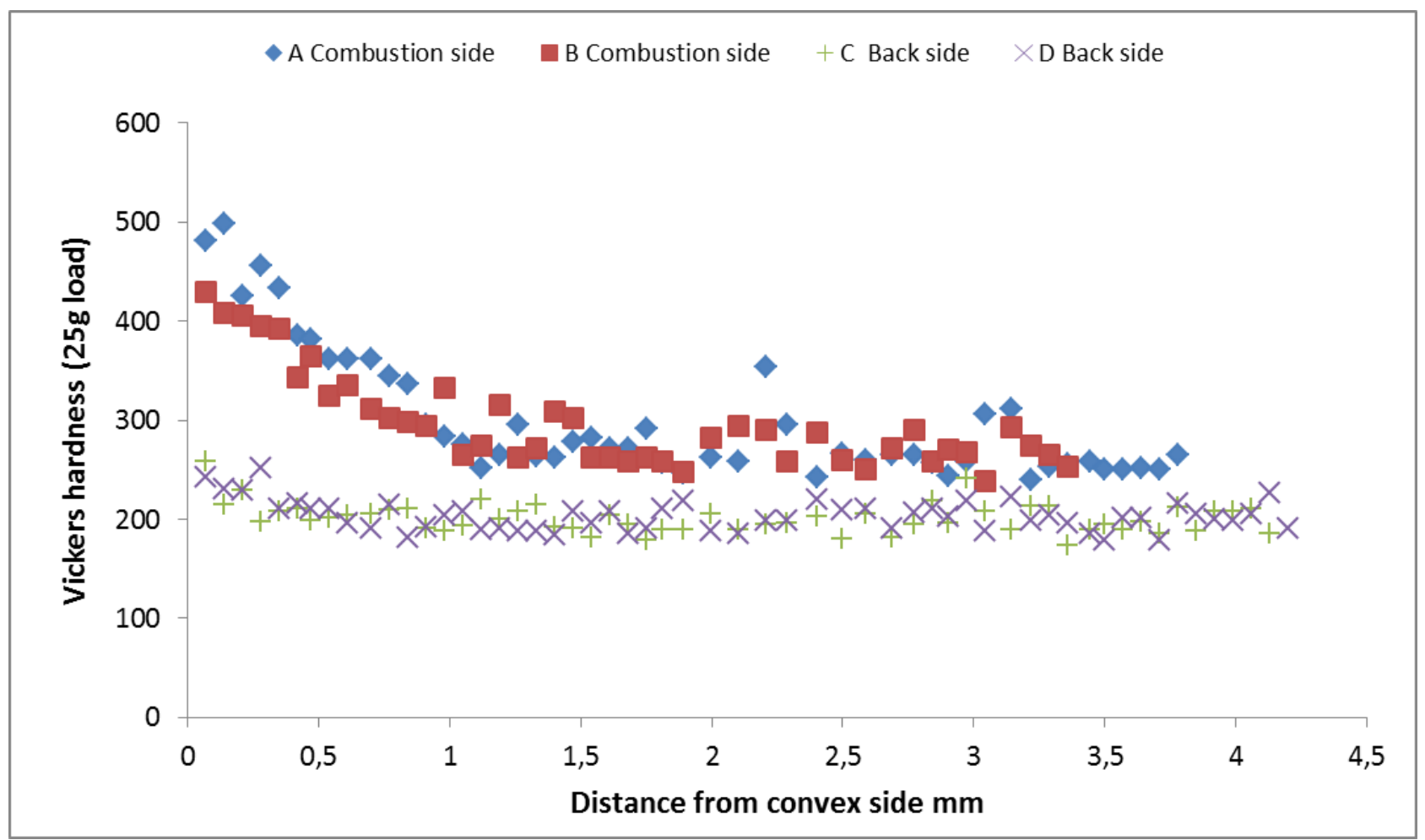

Figure 4: Hardness measurements comparing the combustion side and the backside of the tube.
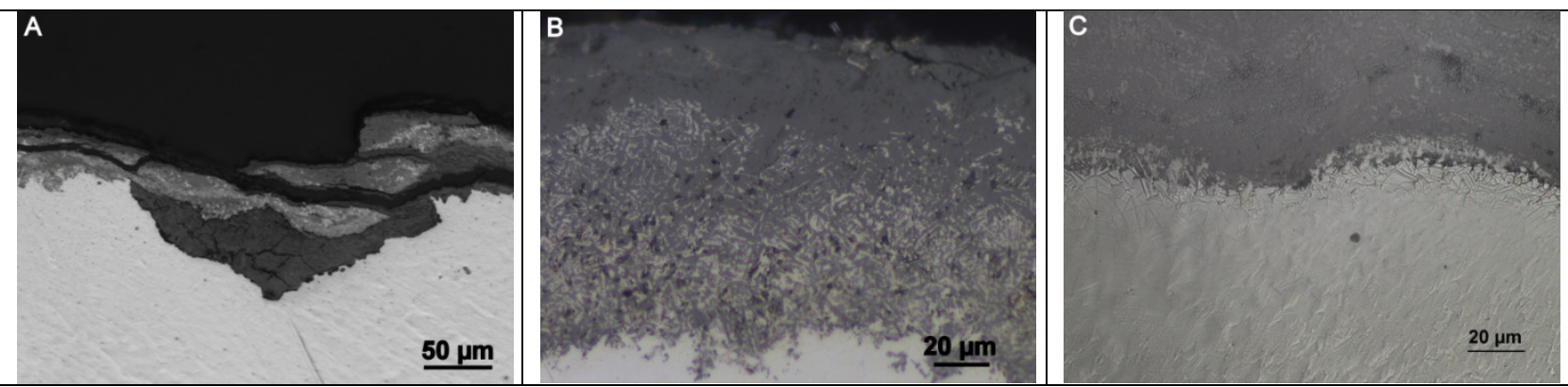

Figure 5: Light optical micrograph (without etching) close to combustion zone showing a) varying oxide composition on surface, b) needle like structures within the oxide and c) at the metallic surface 


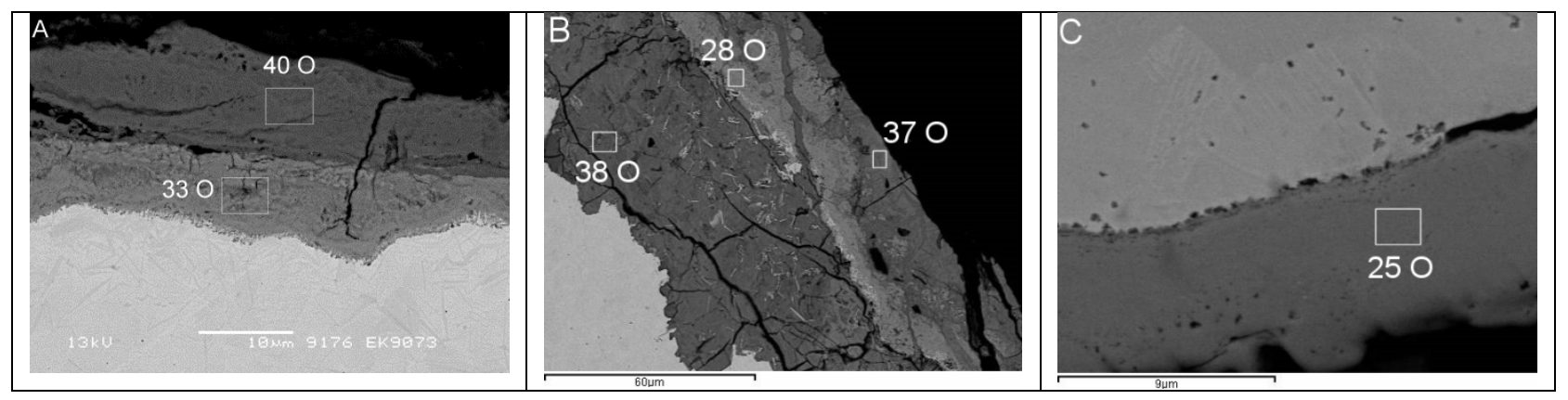

Figure 6: Wt.\% of oxygen measured with $13 \mathrm{keV}$ on different areas of oxide showing different BSE contrast a) and b) are at combustion side and $c$ ) is at steamside. Only Fe and $O$ considered (other elements were $<1 \mathrm{wt} \%$ ).

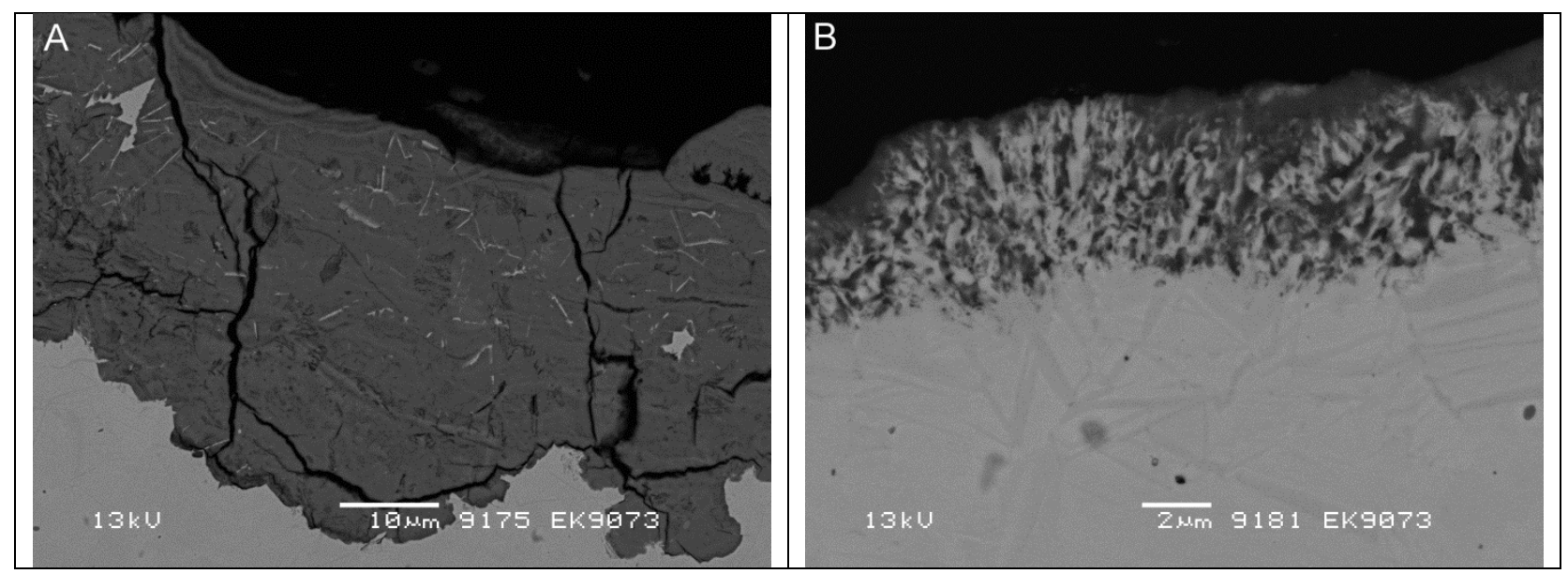

Figure 7: BSE micrographs revealing morphology of different areas at the corrosion front on the combustion side a) acicular structure within a dark oxide b) internal oxidation at the corrosion front. 


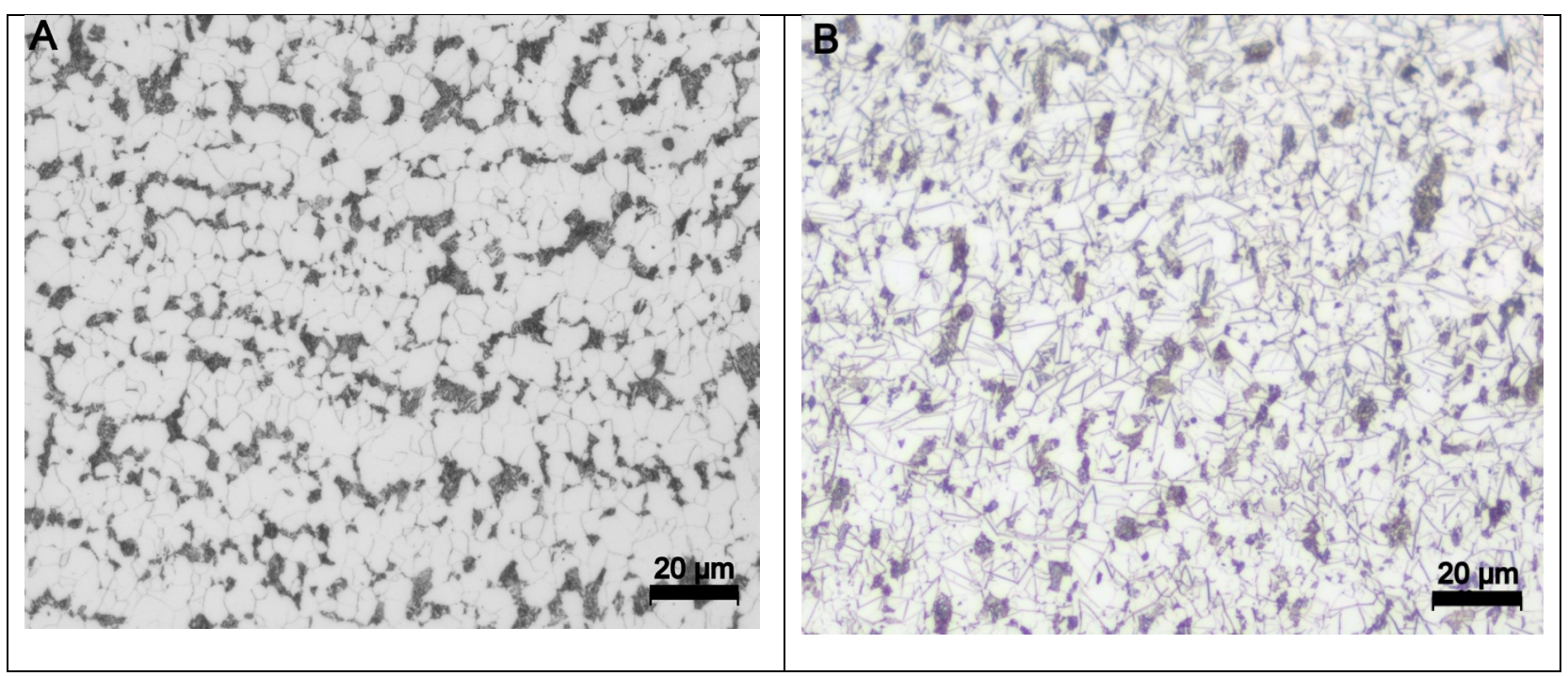

Figure 8: Light optical microscopy after etching revealing a) pearlite-ferrite structure close to steamside b) acicular phase adjacent combustion side.
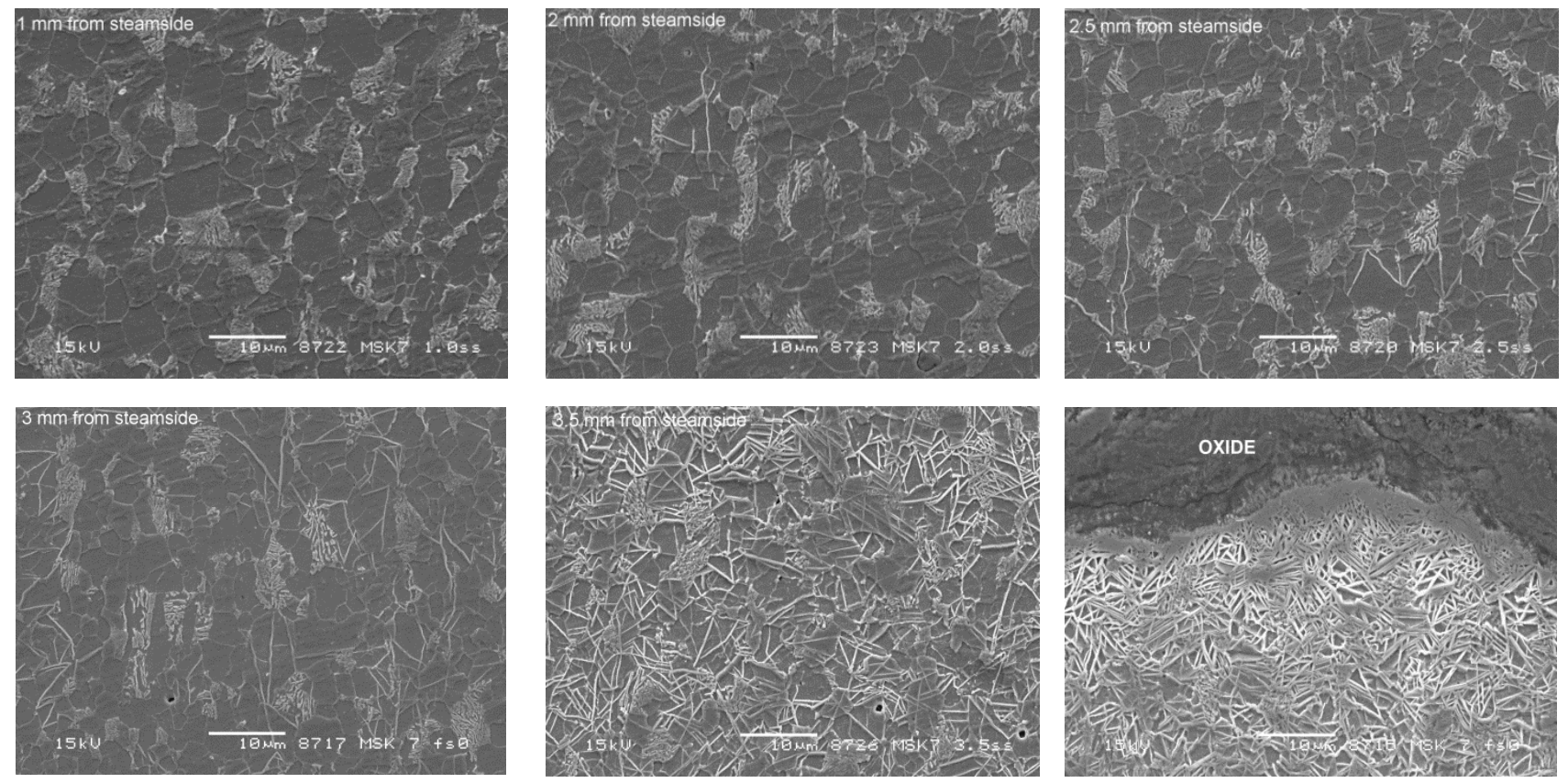

Figure 9: SE micrographs of microstructure on the combustion side showing variation with distance from steamside. 


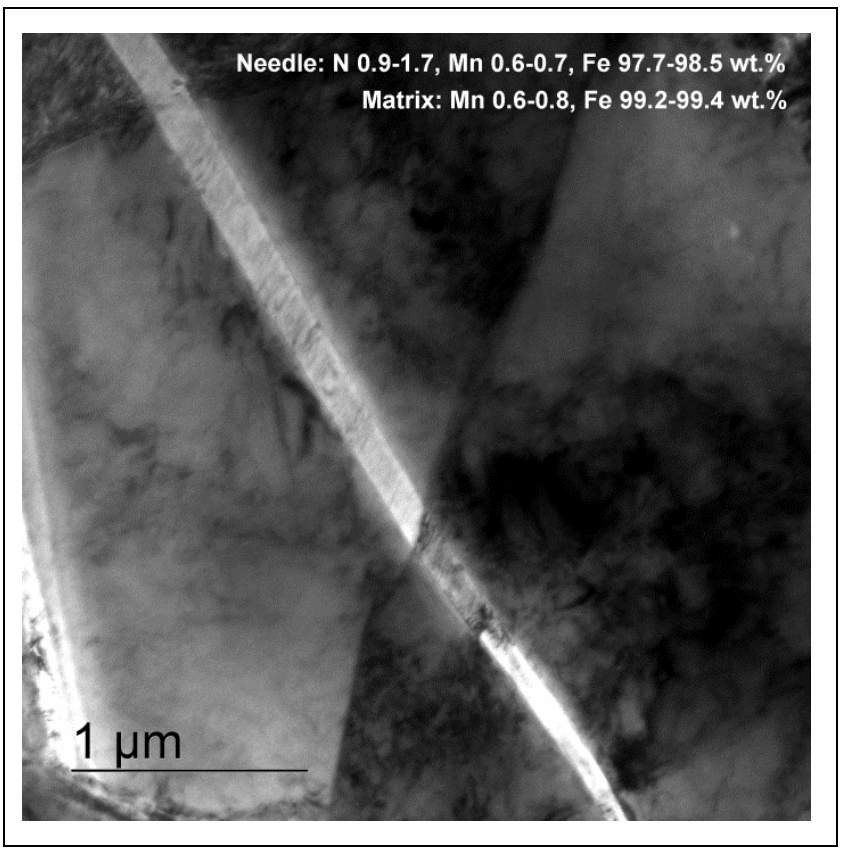

Figure 10: TEM micrograph of needle and EDS analysis of needle and matrix.

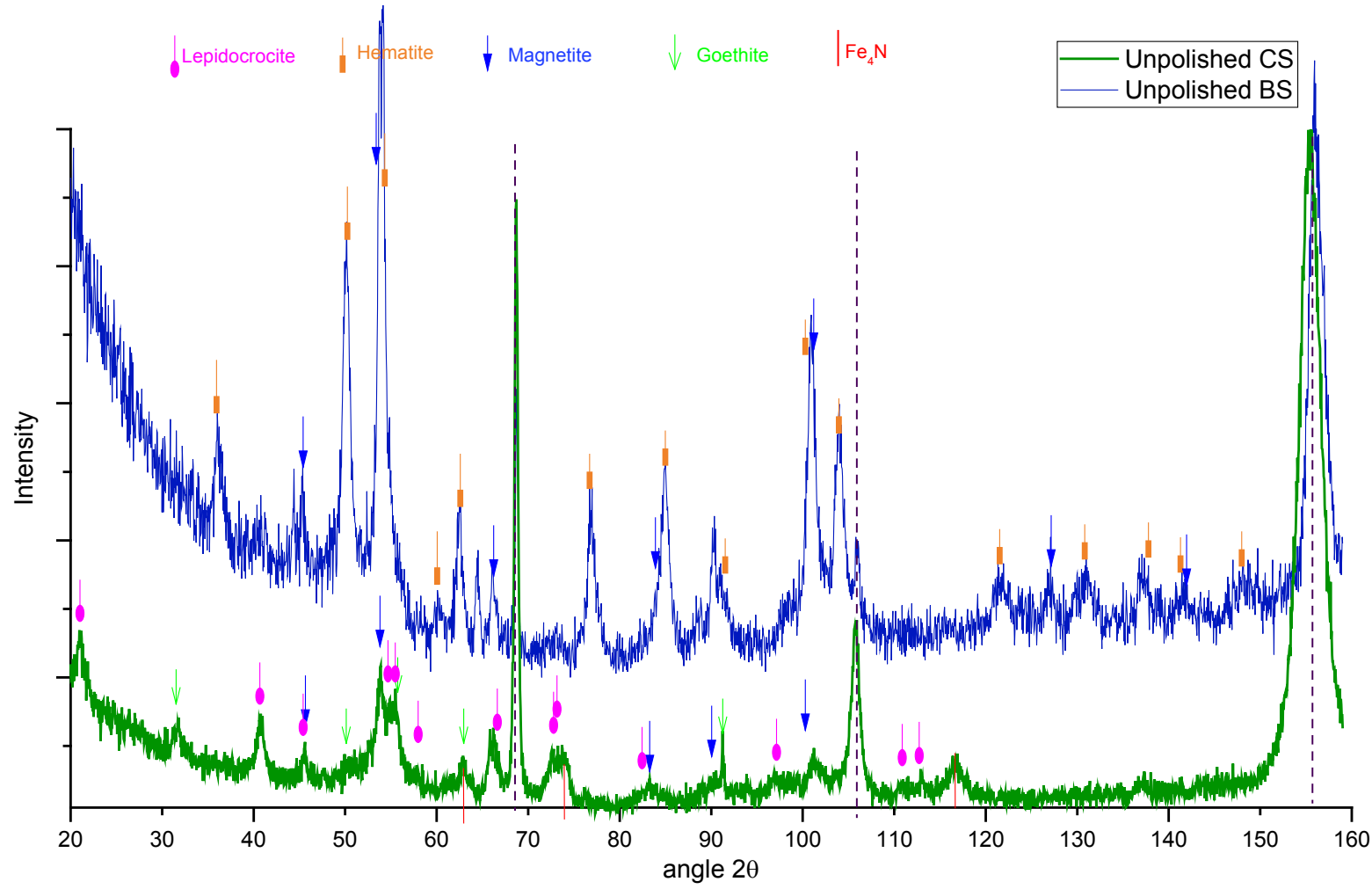

Figure 11: Comparison of x-ray diffractograms from unpolished combustion side and unpolished backside. Dotted line indicates ferrite peaks. 


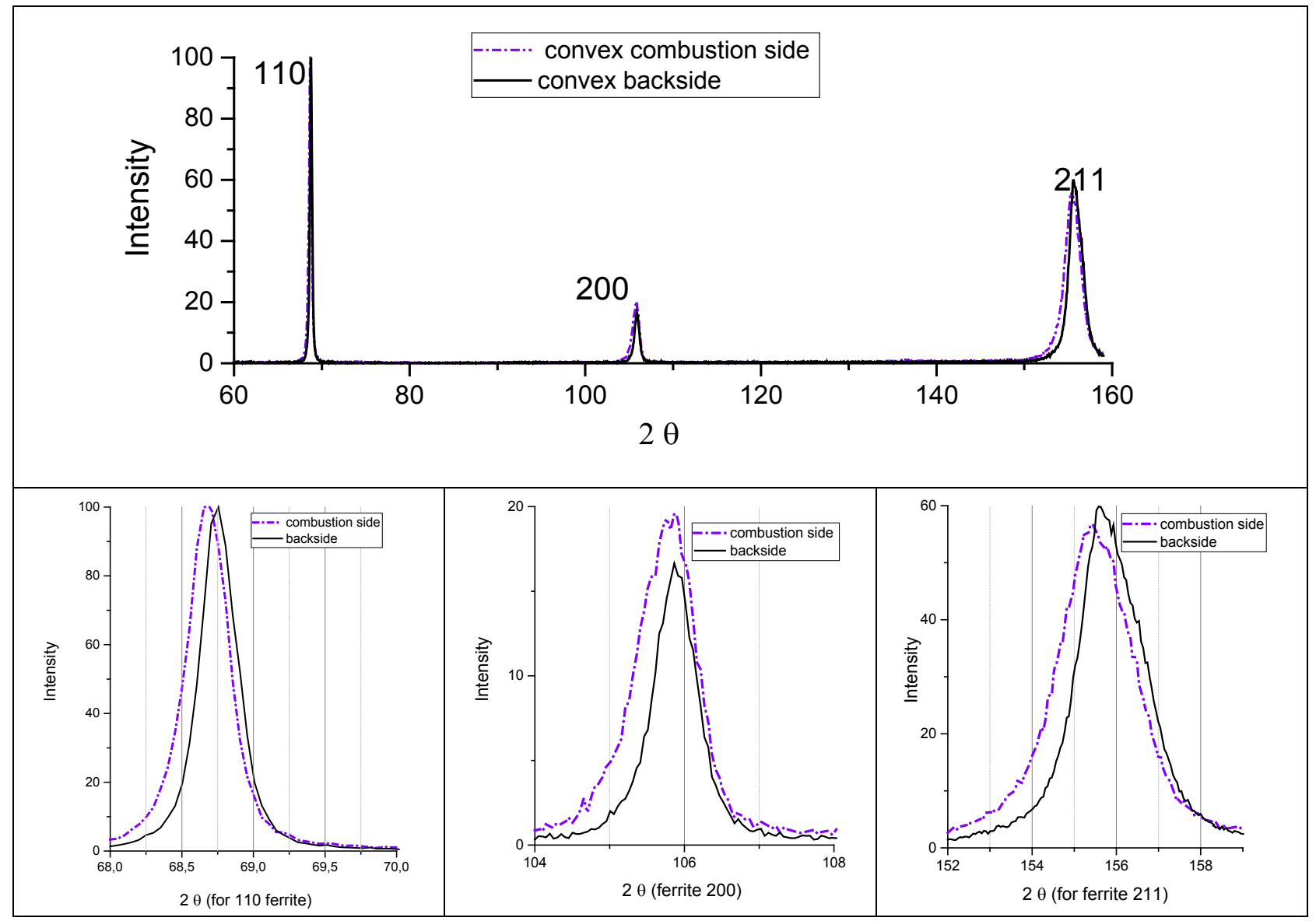

Figure 12: Ferrite peaks on convex side: comparison of combustion side and backside after removal of oxide. 


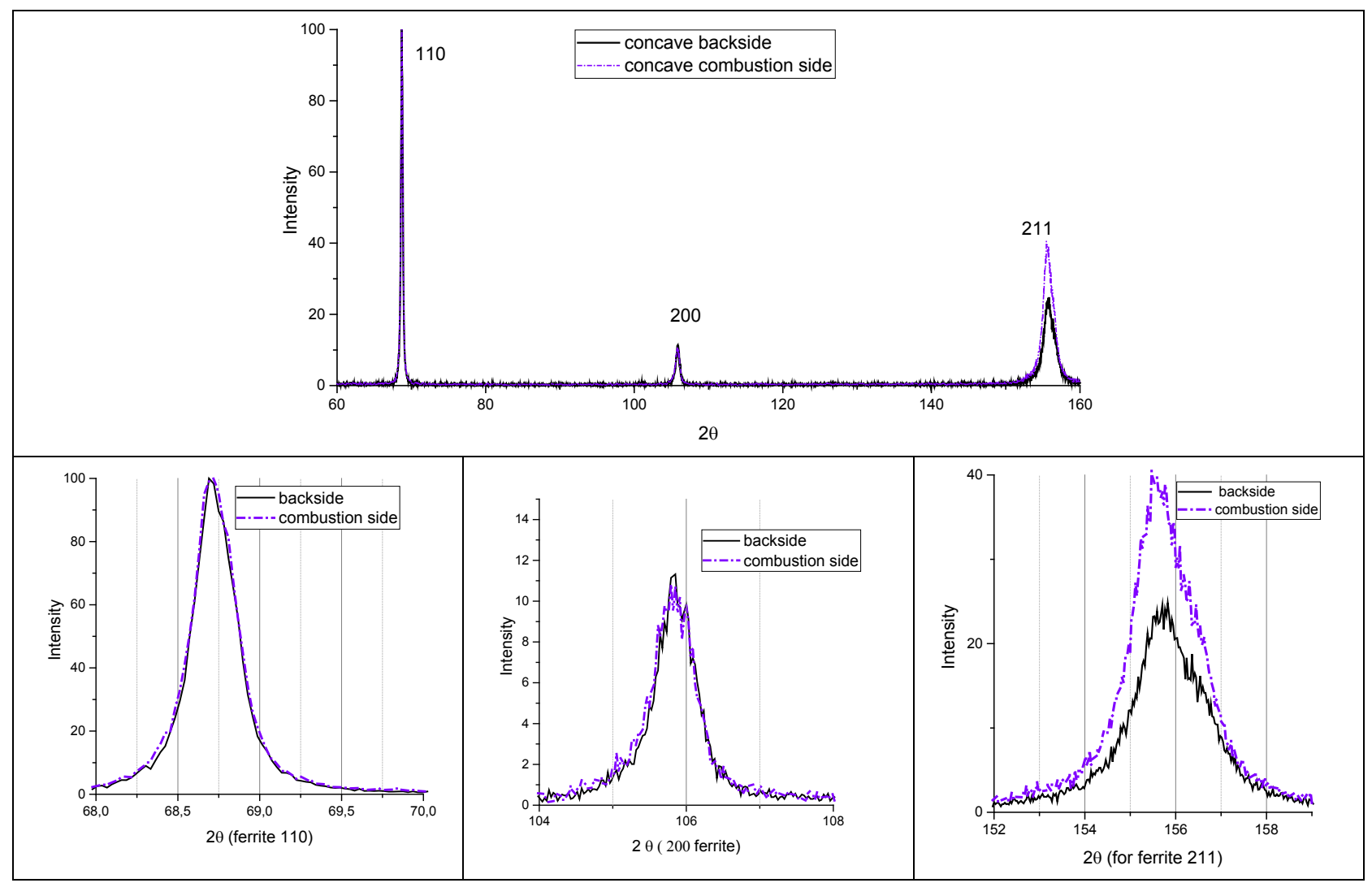

Figure 13: Ferrite peaks on concave side: comparison of combustion side and backside after removal of oxide.

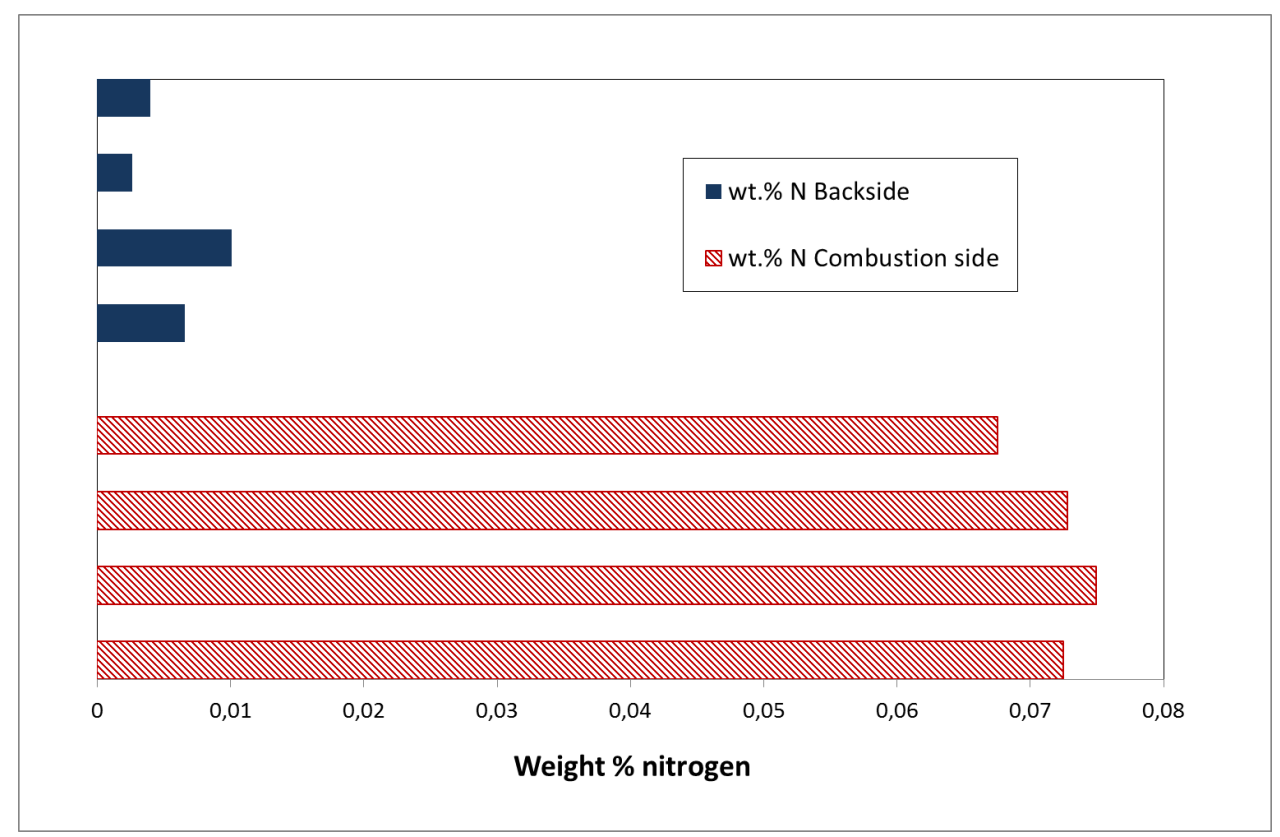

Figure 14: Comparison of nitrogen content from the combustion side to backside of tube on grate. 


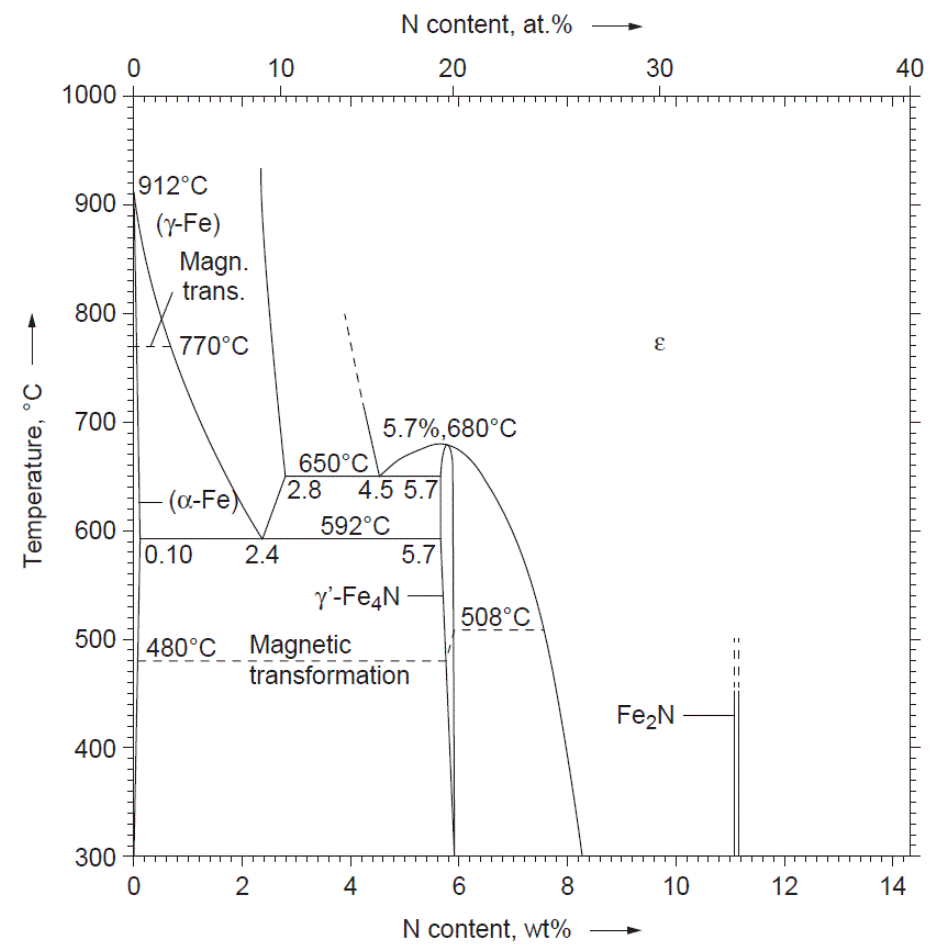

Figure 15: Phase diagram of iron and nitrogen with respect to temperature (reprinted from [4] with permission from Elsevier 2015).

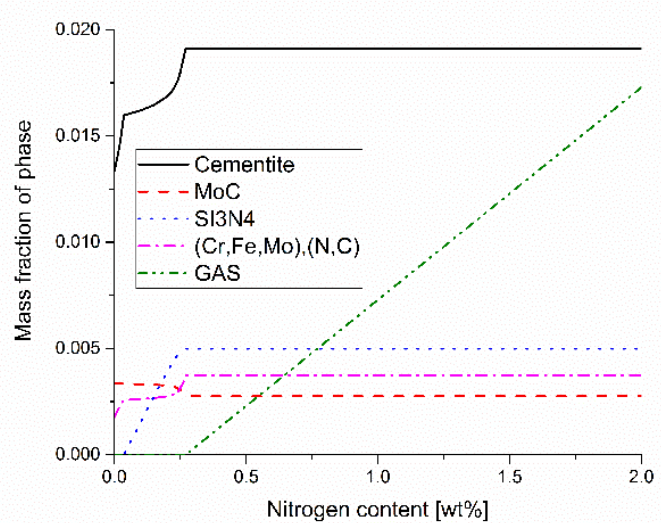

a)

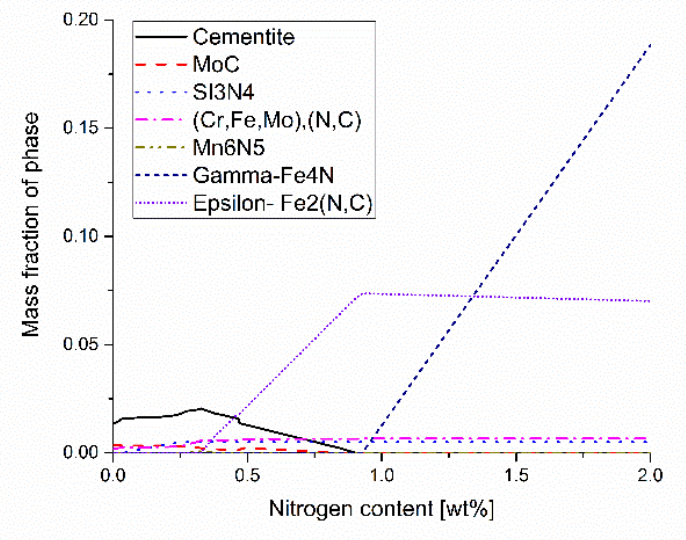

b)

Figure 16: Thermodynamic prediction using ThermoCalc [3] of a) phases present within $15 \mathrm{Mo} 3$ at $350^{\circ} \mathrm{C}$ with increasing nitrogen content, b) calculation where gas phase is suppressed. 


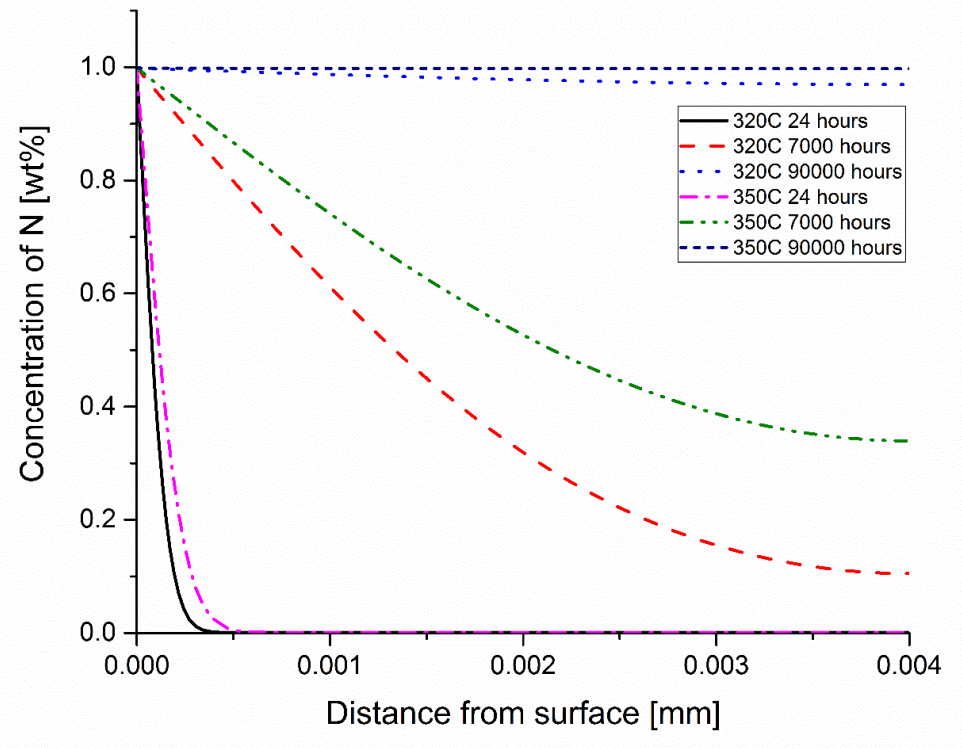

Figure 17: DICTRA simulations [3] to model the nitrogen concentration through a $4 \mathrm{~mm}$ tube with respect to varying times and temperatures. 
TABLES:

Table 1: DIN standard Wkstf 1.5415 for grade 15Mo3 steel (taken from Stahlschlüssel[2]), and nominal analysis and SEM analysis.

\begin{tabular}{|c|c|c|c|c|c|c|c|c|c|c|c|}
\hline & $C \max$ & Si & Mn & $\mathrm{Cr}$ & S & $\mathbf{P}$ & Mo & $\mathrm{Ni}$ & Al & $\mathrm{Cu}$ & $\mathrm{Fe}$ \\
\hline $\begin{array}{l}\text { DIN } \\
\text { standard }\end{array}$ & $0.12-0.20$ & $<0.35$ & $\begin{array}{l}0.40- \\
0.90\end{array}$ & $<0.30$ & $<0.025$ & 0.030 & $\begin{array}{l}0.25- \\
0.35 \\
\end{array}$ & $<0.30$ & $<0.050$ & $<0.30$ & rest \\
\hline $\begin{array}{l}\text { Nominal } \\
\text { analysis }\end{array}$ & 0.16 & 0.3 & 0.6 & $<0.2$ & & & 0.3 & & & & Rest \\
\hline $\begin{array}{l}\text { SEM } \\
\text { analysis }\end{array}$ & $\begin{array}{l}\text { Not } \\
\text { measured }\end{array}$ & 0.52 & 0.79 & 0.09 & & & 0.77 & & & & 97.83 \\
\hline
\end{tabular}

Table 2: Phases identified with $x$-ray diffraction

\begin{tabular}{|c|c|c|c|c|c|c|c|}
\hline & Ferrite & Magnetite & Lepidocrocite & Goetite & Hematite & $\begin{array}{l}\gamma \text {-Iron } \\
\text { nitride }\end{array}$ & $\begin{array}{l}\text { 8-Iron } \\
\text { nitride }\end{array}$ \\
\hline \multirow[t]{2}{*}{ JPCDS number } & $06-0696$ & $19-0629$ & $44-1415$ & $29-0713$ & $72-0469$ & $77-2006$ & $73-2103$ \\
\hline & $\alpha \mathrm{Fe}$ & $\mathrm{Fe}_{3} \mathrm{O}_{4}$ & $\gamma \mathrm{FeOOH}$ & $\alpha \mathrm{FeOOH}$ & $\mathrm{Fe}_{2} \mathrm{O}_{3}$ & $\mathrm{Fe}_{4} \mathrm{~N}$ & $\mathrm{Fe}_{2} \mathrm{~N}$ \\
\hline $\begin{array}{l}\text { Outer corrosion products } \\
\text { removed from combustion } \\
\text { side }\end{array}$ & & $\mathrm{x}$ & $\mathrm{x}$ & $\mathrm{x}$ & & & \\
\hline $\begin{array}{l}\text { Unpolished convex } \\
\text { combustion side }\end{array}$ & $\mathrm{x}$ & $\mathrm{x}$ & $\mathrm{x}$ & & & $\mathrm{x}$ & \\
\hline Unpolished convex backside & $\mathrm{x}$ & $\mathrm{x}$ & & & $\mathrm{x}$ & & \\
\hline $\begin{array}{l}\text { Semi polished convex } \\
\text { combustion side (so both } \\
\text { oxide and steel were visible) }\end{array}$ & $\mathrm{x}$ & & $\mathrm{x}$ & $\mathrm{x}$ & & & \\
\hline $\begin{array}{l}\text { Polished convex combustion } \\
\text { side }\end{array}$ & $\mathrm{x}$ & & & & & $\mathrm{x}$ & $\mathrm{x} ?$ \\
\hline Polished convex backside & $\mathrm{x}$ & & & & & & \\
\hline $\begin{array}{l}\text { Polished concave } \\
\text { combustion side }\end{array}$ & $\mathrm{x}$ & & & & & & \\
\hline Polished concave backside & $\mathrm{x}$ & & & & & & \\
\hline
\end{tabular}

Table 3: Summary of results from combustion side and backside of the tube

\begin{tabular}{lll}
\hline Techniques & Combustion side & Opposite side \\
\hline Microscopy & Acicular structure in steel + ferrite/pearlite & Ferrite/pearlite \\
\hline Microhardness & Higher hardness at convex side & Same hardness through tube \\
\hline XRD of bulk & Shift and broadening in ferrite peak & Ferrite peaks \\
\hline XRD of oxide & FeOOH and $\mathrm{Fe}_{3} \mathrm{O}_{4}$ & $\mathrm{Fe}_{3} \mathrm{O}_{4}$ and $\mathrm{Fe}_{2} \mathrm{O}_{3}$ \\
\hline LECO analysis & 0.07 wt. $\% \mathrm{~N}$ & $<0.01$ wt.\% $\mathrm{N}$ \\
\hline
\end{tabular}


Graphical Abstract:

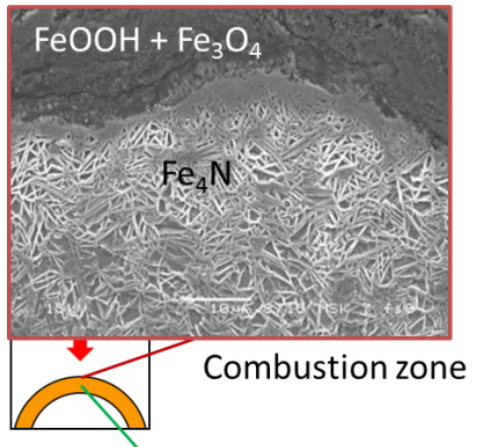

There were problems in repair welding of a biomass grate tube operating at $350^{\circ} \mathrm{C}$ for 16 years. Using various microscopy and analysis techniques, it was revealed that a) $\mathrm{FeOOH}+\mathrm{Fe}_{3} \mathrm{O}_{4}$ was present as a corrosion product and b) nitridation had occurred on the tube closest to the combustion zone where $\mathrm{Fe}_{4} \mathrm{~N}$ acicular phases were identified. This phase will be unstable during welding resulting in release of nitrogen gas.

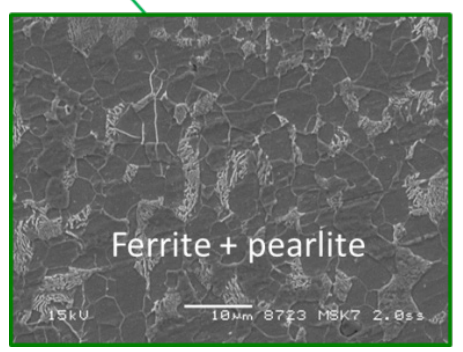

